\title{
Possible worlds and the beauty of God
}

\author{
MARK IAN THOMAS ROBSON \\ St Robert of Newminster Catholic School, Biddick Lane, Washington, Tyne and Wear, \\ NE38 $8 \mathrm{AF}$ \\ e-mail:Robson.M1@sunderlandlearning.net
}

\begin{abstract}
In this paper I explore the relationship between the idea of possible worlds and the notion of the beauty of God. I argue that there is a clear contradiction between the idea that God is utterly and completely beautiful on the one hand and the notion that He contains within himself all possible worlds on the other. Since some of the possible worlds residing in the mind of the deity are ugly, their presence seems to compromise God's complete and utter beauty.
\end{abstract}

In this paper I want to explore the relationship between the idea of possible worlds and the notion of the beauty of God. I argue that there is a clear contradiction between the idea that God is utterly and completely beautiful on the one hand and the notion that He contains within himself all possible worlds on the other. Since some of the possible worlds residing in the mind of the deity are ugly, their presence seems to compromise God's complete and utter beauty. ${ }^{1}$ Let me try to give the reader an idea of the contradiction by way of this short parable:

You have been invited to the house of a saintly person who is famed throughout the land for the beauty of her thoughts. Indeed, such is her fame that she is often called Wisdom. Shortly before you arrive, as a dutiful preparation for your visit, you read some accounts of this person's beauty. You read witness reports like the following:

... she is more beautiful than the sun, and excels every constellation of the stars. Compared to light, she takes precedence; for that, indeed, night supplants, but wickedness prevails not over Wisdom. Indeed, she reaches from end to end mightily and governs all things well. Her I loved and sought after from my youth; I sought to take her for my bride and was enamoured of her beauty. ${ }^{2}$ 
Another writer is also full of praise:

In her there is a light I love, and a food, and a kind of embrace when I love her - a light, voice, odour, food, embrace of my inner man, where my soul is floodlit with light which space cannot contain, where there is sound that time cannot seize, where there is a perfume which no breeze disperses, where there is a taste for food no amount of eating can lessen, and where there is a bond of union no satiety can part. ${ }^{3}$

The same writer in a very famous passage declares:

Late have I loved you, beauty so old and so new: late have I loved you ... . You called and cried out loud and shattered my deafness. You were fragrant, and I drew in my breath and now pant after you. I tasted you, and I feel but hunger and thirst for you. You touched me, and now I am set on fire to attain the peace which is yours. ${ }^{4}$

You read in The Divine Names: 'And they name her beautiful since she is the allbeautiful and the beautiful beyond all. She is forever so, unvaryingly, unchangeably so .... She is the superabundant source in herself of the beauty of every beautiful thing. ${ }^{5}$ There are numerous other references to her beauty, although you note that recent writings about this person concentrate more on her possession of knowledge and power. This, you find, a little disappointing. ${ }^{6}$

Having found such wonderful promises about this person, you are understandably keen to meet her face to face. The time comes and with infinite grace and gentleness, she approaches. She is so beautiful that you find yourself feeling foolish for finding anything else beautiful before. You say to yourself: 'This is beauty - sheer, utter, unadulterated beauty. Anything else is only a pale reflection of this.'

Being a philosopher, however, you are keen to know her thoughts. She is famed for the beauty of her reflections, her contemplations, the wonderful stories she can tell. Sitting before her, she tells stories to you of such sheer ingenuity, originality, style and beauty that you find yourself feeling an awesome inspiration. Sometimes the stories are comfortable, relaxing - you feel intensely calm, meditative. In other stories - more sublime - you feel as if confronted by the terror of a mountain or an infinite abyss. But behind the awe-inspiring terror, you feel an all-encompassing love such as a parent would feel to its offspring, but immeasurably more intense.

You ask her: 'Are these your thoughts, Beautiful One, or are they copied from elsewhere?'. She replies, 'Yes, they are mine. There is no other but myself who is the source and originator of these stories of great beauty. I copy from nowhere, but look only inward at the infinite reserves of my own contemplations.' You think to yourself: 'Her thoughts are beautiful, so wonderful, so inspiring. They are noble, grandiloquent - you can hardly find words adequate to express their wonderfulness. And she is their originator!' You remember the lines of another worshipper of this person:

She takes absolutely nothing from any other source, whence it might either frame a model in itself, or make its creatures what they are; while the mere human artist is 
wholly unable to conceive in his imagination any bodily thing, except what he has in some way learned from external objects .... .

And again the same author expresses her originality like this: 'it is equally certain that whatever she created, she created through nothing other than herself; and whatever she created, she created through her own most intimate expression'. ${ }^{8}$

'Let me tell you another of my stories', she says gracefully, with a voice so utterly sweet and gentle. You settle down thirsting for another beautiful story. You love this exploration of her mind. However, your eagerness turns sour as her new words unfold. You find yourself feeling uncomfortable, then feeling physically sick. The story she tells you is an incredibly detailed tale of the rape and murder of a child. Nothing is left to the imagination. The story is so detailed, so minute in its descriptions that it is as if the terrible events are unfolding before your very eyes. It is a story of such ugliness that you are appalled.

Then, despite your protestations, she launches into a story of how Hitler conquers Europe, takes his murderous policies all over the planet and then establishes a galactic empire that takes never-ending, sadistic delight in killing the innocent. The story exactly parallels what the real world would be like were this possibility to have been actualized. She tells another tale. This time she tells you a narrative whose horror is so acute, so perverse that no mere human mind would have been able to originate such filth.

'Beautiful one', you respond (you find this epithet less appropriate now), 'again I ask "are these stories part of yourself, or do you look outwardly at another source?" '. 'My child, they are part of me and I have other tales of such perversity, such dreadfulness, of such moral depravity that your mere finite mind could not even to begin to comprehend the sheer horror of their ugliness. I have possessed all these stories for all eternity. Never once has any part of them been lost from my consciousness. I have contemplated their appalling nature for all time. Even as I see you now I am vividly aware of the story of you being tortured to death on a rack. This story is, also, an eternal part of who I am.'

As you leave, you recall Augustine's words about her beauty, her peace, her fragrance, but with the taste of bile still bitter in your mouth and your mind reeling at the ugliness of the stories she uttered, you find these words very hard to believe.

What have I tried to convey in this parable? I have tried to alert the reader to a problem I think exists. I have presented the problem in a dramatic and deliberately shocking way. It seems to me that many of us are so used to the idea of possible worlds that we employ the idea without much perception of its hidden, theological dangers. Let me draw attention to the central ideas I tried to convey in the parable:

First, the stories God tells (the woman, of course, represents God) are meant to be the equivalent of possible worlds or, to put it another way, they are the 
possible world books that God possesses as a part of His contemplations. ${ }^{9}$ In this model of God's understanding, God eternally contemplates a whole host of possible worlds. These worlds are understood to be maximal, determinate, and represent every possibility. ${ }^{10}$ Basically, the idea is that God knows what His creation will be like by looking toward these possible worlds. He examines these as a kind of prelude to creation. Second, these worlds are usually understood (in best Christian Platonist fashion) to be part of God. Unlike the Demiurge, God looks inwards at Himself to find these possible worlds, and so His aseity is preserved. He relies on no other thing but Himself in order to effect the creative act. Third, the worlds are eternal. They are eternal parts of the divine being. ${ }^{11}$

My argument is simple. Given this understanding of possibility, i.e., that God possesses from all eternity ugly, depraved, terrible stories representing every ugly possibility, then, how can He be utterly and completely beautiful ${ }^{12}$

For the rest of this paper I will consider what a possible-worlds' theorist could offer in defence of the claim that his model of the divine mind does not compromise the divine beauty. I will consider the following replies:

(1) Possible stories are neither ugly nor beautiful - only if they become actual can they be ugly or beautiful.

(2) God's beauty consists of a union of truth and goodness. God has to know the truth of what is possible if He is to be beautiful, even if those truths are themselves horrible. His goodness means that He looks upon these horrible truths with a healthy hatred.

(3) The conception of beauty I am working with is not up to scratch since it is sentimental. True, unsentimental beauty can cope with ugliness and defeat it, so that the narrative is made beautiful.

(4) God's beliefs are so wholly unlike ours that my parable fails to tell the truth of what God's cognizance of stories of possible events is like.

Let us look at the first reply. Here the Leibnizean ${ }^{13}$ claims that only if the stories become actual, can they be understood to be ugly or beautiful. He might begin his argument by saying that this is, for example, true of the moral goodness or evil of possible actions. If I contemplate the possible evil of a particular action (and, on that basis, reject it) I have not been morally compromised. Merely entertaining the possibility of an evil action does not affect me morally. ${ }^{14}$ To put it another way, a possible evil action is only really evil if it is actualized; if, that is, it becomes real. Possible evil worlds are only evil if they come to be. Arguing in a parallel way, the Leibnizean claims that stories of possible ugliness are only really ugly if they are actualized - if, that is, they become real. The same, of course, would be true of beautiful stories.

I do not think that this reply works. We might accept that mere possibilities cannot be evil or good, but we do say of stories that they are beautiful or ugly. When I say of a story that it is ugly I do not just mean that if the story were 
to become true it would be ugly; I mean the story itself is ugly regardless of whether or not the events it describes become real. ${ }^{15}$ To claim that stories themselves - regardless of their actualization - cannot be aesthetically judged would surely be an outrageous claim.

Now the Leibnizean might reply that a more nuanced understanding of what it is for a story to be ugly can save the day. He might say that, strictly speaking, no story is in itself ugly or beautiful - it is only the telling of the story that deserves aesthetic approbation or disapprobation. Here the Leibnizean separates content from form and claims content is aesthetically neutral, while form (the way the story is told) is amenable to aesthetic judgement.

Doubtless, there is something in this claim - the drab and the mundane can be transformed by the form, but I doubt whether this kind of transformation is always possible. If it is always possible, then, all stories can be beautiful if they are told well. The form always has the final word. This is hard to believe. Let us return to our parable. Imagine Wisdom after seeing your reaction to the child rape and murder story assures you with the words, 'But haven't I told it with flair and charm and an eye for detail?'. I do not think you would be convinced. I think that the content is just intrinsically ugly regardless of the form in which it is conveyed. What is true for a child rape and murder seems even more true of other such horrors as the story of a possible galactic holocaust.

In any case, exactly what form is God supposed to use? According to the typical Leibnizean, these stories must represent exactly what the actual event would be like in all its detail. I tried to show this point in the parable when I mentioned the minute detail of the story that Wisdom tells. The story I said 'exactly parallels what the real world would be like were this possibility to be actualized'. There can be no extraneous, technical flourishes on God's part, no blurred, impressionistic representations. He must, it seems, faithfully copy for all eternity what the rapist would do if the rapist were to rape and murder a child. ${ }^{16}$ Here, it seems, the content masters the form and completely overwhelms it. ${ }^{17}$

Of course, many great works of art represent scenes of great ugliness. There are, for example, Picasso's Guernica, and Matthias Grünewald's Isenheim Altarpiece. These are indeed great works of art but it is hard to believe that anyone considers them beautiful in themselves. Indeed, we think of them as ugly, but their intrinsic ugliness is mitigated by the painter's skill in the mastery of form. We, also, value such great works because of the way they make us think of the pervasiveness of suffering in the world. ${ }^{18}$ It is worth recalling here that the Leibnizean has to show that there is no vestige of ugliness whatsoever in God's stories of possible events. Any ugliness, no matter how minuscule, will sully the purity of the divine beauty. The ugliness of Wisdom's story of child rape may be softened by her absolute hatred of it, but is all the ugliness completely obliterated $?^{19} \mathrm{I}$ do not think so. ${ }^{20}$

Let us summarize our conclusions. (1) Stories do not have to wait to be actualized before they are ugly. I take this point to be obvious. (2) Form may help to 
transform content, but some content is so ugly that no amount of amelioration by form can remove all the horror. In any case, I have argued that God must faithfully represent the horror. He must obey the dictates of the rapist's possible actions. God cannot transform the actual content; the narrative must be a faithful copy of the action.

It is now time to look at another, perhaps more promising line of reply. God's beauty does not stand alone says the Leibnizean - it is a union of truth and goodness. ${ }^{21}$ The argument might go something like this: God's beauty contains all truth. Because He contains all truth He must contain all the truths about what is possible. It is an eternal truth about possibility that if free agents were to exist then some of them might freely choose to commit rape and murder. God sees these agents and He sees their possible acts. His goodness means that He sees that this possibility, if made actual, would be a great evil. He uses this knowledge to find the truth of what an actual world would be like. He weighs these matters employing His moral perfection to create the world which is reported in Genesis as being 'good'. As part of the magnificent omniscience and moral perfection of God, even these terrible stories are involved in His beauty.

The Leibnizean might put it in this way: it is a perfection or part of God's perfection that He knows what the rapist and the murderer might do. Imagine a God at a loss to know what the rapist might do next - such a God would be always being caught out by creation! He would not appear to be perfect-He would be a being who might well be unworthy of our worship. So we need these stories - horrible as they are - if we are to worship one who properly deserves our praise.

I think that this reply fails. First, is it really part of perfection to be the ultimate ground of these stories ? $^{22}$ I have no problem with a God who looks outwardly at the actual rapist and murderer and knows their possibilities, their capacities, their desires, their thoughts - indeed, just like the Leibnizean, I want Him to know what these people might possibly do. This is a God who sees possible evil in creation itself. Such a God sees ugliness (and moral imperfection) outside of Himself. But in the Leibnizean picture, we have a God who before creation is even actual, looks inside Himself and sees the rapist performing his possible actions. Such sights or such stories would be ugly, and their ugliness would not be exterior to the divine being but be a part of His very essence. This is bad enough, but for the Leibnizean, these stories continue to inhabit God for all eternity. As I tried to suggest in the parable, presumably there are darker, more perverse, more ugly stories inside the divine being - whole worlds of sadism, whole worlds of rape, whole worlds of holocausts.

Second, even if the Leibnizean were to show that God's being the ultimate ground of all evil is not morally compromising, it would not answer the principal charge being pursued in this paper that it is aesthetically compromising. According to the typical Leibnizean, the realm of possibility is a set of discrete worlds or 
world books. If it is possible that a world of child rape and murder can exist or worlds of galactic holocausts, then, these are individual worlds or stories in the mind of God. They do not form a uniting part of some aggrandizing, beautiful vision; instead, they seem to be ruinous blots on the landscape of the divine contemplations. Being individual worlds representing what is possible in that individual world, they are units of ugliness, individual paintings, if you will. We may try to put them in a fancy frame, but the ugliness of their content is still present. Some parts of God, it appears, must be ugly. It does not seem to me that we can integrate these ugly, possible worlds together to make some kind of beautiful whole.

Let me summarize the argument: we might be able to show why it is not morally objectionable for God to be - in some way - the ground of the possible actions of a possible rapist, but we cannot make the rapist's possible actions beautiful, even by trying to make these possible actions part of some grander scheme. The rapist's possible actions are ugly in themselves. God's stories of what possible rapists might do must carefully represent each part of the rapist's actions. How can these kinds of story be made beautiful?

Now the Leibnizean might put his objection in a different way. He might say, 'Do we want God to be ignorant of what is possible? Surely the resultant blanks, the lacunas in God's mind would be a serious lack - a kind of ugliness. Knowledge is more beautiful than ignorance, even if that knowledge is knowledge of ugly things.' The question is this: does denying God access to knowledge of possible worlds leave Him with an ugly ignorance? This entirely depends upon whether one thinks that there is an ignorance being introduced into the divine being. As open theists often say, their denial that God does not know what free agents are going to do is not necessarily a limitation on omniscience. ${ }^{23}$ More correctly they are putting forward a thesis about ontology, or what is there. Similarly, if possible worlds do not exist in any shape or form, then there is no denial of divine omniscience if we say that God 'cannot' know them. Such things as possible worlds may be just unpleasant figments of the philosophical imagination. If they are really just figments, then, no ignorance is introduced into the divine being.

Now let us consider another objection to our argument. I might be accused of a having an incomplete notion of beauty - perhaps the notion of beauty that is implicit in this essay is a prettified, cosy kind of beauty. ${ }^{24}$ Beauty, properly understood, is not sentimental. As Jeremy Begbie claims in an excellent recent essay, beauty is sometimes unveiled after a period of darkness. ${ }^{25}$ He says that the darkness or ugliness of Holy Saturday is a part of the drama of the eventually vindicating Easter story. I agree with Begbie. I agree that the transforming power of God, especially in the Cross, can defeat darkness, and that the overall story that Christianity offers is a positive, victorious one, despite the horrors. God will defeat darkness, and that defeat of darkness will be an unsentimental beauty, one that looks evil in the face, but eventually defeats it. ${ }^{26}$ 
Unfortunately, however, this is not the vision God will have in some of His possible worlds, the stories which are an eternal part of Himself, the stories that He eternally has as part of His very essence. Every possibility is represented in these worlds. We might agree, for the sake of argument, that the only worlds God would actualize would be those worlds in which He redeems all and defeats the ugliness, and His triumph is seen as an unsentimental, beauteous victory.

But what of those darker worlds which God would never actualize? ${ }^{27}$ What of those possible worlds where He does not redeem the victim and free the enslaved? These worlds - which God would never actualize - are, according to our typical Leibnizean, present in the mind of God. They are possible, it is said, because they are internally self-consistent sets of events. Consequently, there will be myriads of possible world stories where sadistic torture is eternal, and injustice reigns for all time, where the child murderer carries on delighting in his perversion. We can delight in the fact that God turns His face away from these worlds in the sense that He does not allow them to be actualized, but nevertheless they are still there as possible stories in God's mind. They represent the possible ways worlds would be if those worlds were to be unredeemed. They would be ugly worlds without a trace of the divine victory.

Finally we turn to the last objection to the idea that God's stories of possible events compromises the divine beauty. Linda Zagzebski discusses William Alston's claim that we must not think of God literally having beliefs. Beliefs are units or chunks of information, and it seems wrong to think of God's access to knowledge being parcelled into the sub-units or chunks that beliefs provide. Finite sentient agents, of course, have to believe in a multiplicity of truths, some about this and some about that. Our access to reality is, it seems, irredeemably chunky. Alston's suggestion, which is inspired by Aquinas, is that God's access to knowledge is radically different. According to this claim, all is seen in one undifferentiated vision. So instead of propositional units (which are for us the mediating objects of beliefs), God sees all truth directly in one grand vista.

Linda Zagzebski is sympathetic to Alston's account. In her discussion she combines his idea that God's access to the truth is not via the mediating units of belief with the Thomist notion that God's primary vision is Himself. She writes:

\footnotetext{
Primarily and essentially God knows only himself. To know anything else would be to focus the divine gaze on the imperfect. But in his simple and direct intuition of his own essence, God knows secondarily everything else. This is because God's essence contains exemplars of the infinitely many ways his essence can be represented in finite reality: 'God knows Himself as primarily and essentially known, whereas He knows other things as seen in His essence. ${ }^{28}$
}

To understand this idea and to explain how God is able to know the contingencies of the created world even though His conception is of Himself, Zagzebski suggests using an analogy from the act of human vision. Imagine, she 
says, seeing a young man's face. ${ }^{29}$ This is the primary act of seeing. It is a single act of vision - one sweeping influx of visual information. Now, she explains, primary acts of vision can have different secondary objects as well. Let us suppose that we see the mother's features through our primary act of seeing the young man's face. It is a familiar enough experience. This secondary object is, Zagzebski notes, a mere accidental property of the first vision. Given a visually different mother would mean you 'see' another secondary object. In other words, it is not an essential part of the primary vision that the secondary object is what it is.

Now she applies this analogy to God's knowledge.$^{30}$ God sees only Himself. His primary vision is His own beautiful perfection. Secondary objects of the divine primary vision are different depending upon what the world is like. As we have said, these secondary objects are merely accidental, and because of this they are able to reflect the contingencies of the actual world. Just as visually different mothers could be 'seen' even though the face of the son remains the same, God sees different worlds even though His primary vision is necessarily identical.

Now we are in a position to explain how an objection to my account could go. The objector argues that God's vision is only Himself. This vision is, of course, pure, unadulterated beauty. Stories of possible rapes and murder (ugly stories) are known only 'through' this vision of unalloyed beauty. These are merely the secondary objects of the divine contemplation; primarily His vision is of Himself. An objector could argue that such an account saves God from the compromise of ugliness. After all, God only sees the beauty of the divine perfection.

Does this account work as an objection to my argument? First, I have to admit to being attracted to the Thomist understanding that God's access to the truth of things is direct and undifferentiated. It does not appear to me to be plausible to understand God's knowledge as being parcelled up into units. Alston's account seems to avoid an implausible and unwelcome anthropomorphism in our understanding of divine knowledge. Zagzebski's addition that God knows the (accidental) vagaries and imperfections of this world through the primary vision of Himself is ingenious and thought-provoking. I do not, however, think it can be used to avoid the charge that God's knowledge of the possible compromises His beauty. The crucial difference is that God's vision of the possible is not, according to the Leibnizean, a merely accidental feature of the divine contemplation. Orthodox Leibnizeans are committed to the necessity of the possible. God's knowledge of the possible is not, therefore, a mere accidental object of the divine vision. God, according to the Leibnizean, sees all the possibilities that there are, and He sees them as necessary objects of His contemplation.

Given the necessary nature of God's musings concerning the possible, it is hard to understand in what sense they could be mere secondary objects of the divine vision. Certainly we can accept that what becomes actual is a contingent matter - perhaps Zagzebski's idea might be used here to avoid the charge that God's everlasting knowledge of actual rapes compromises the divine beauty. But 
what is possible is not contingently possible - it is a necessary part of the divine understanding. ${ }^{31}$ It appears, then, that ugly stories of the most appalling kind would be an integral, essential part of the divine self and so ruin the beauty of the divine vision.

As I say, I accept that God's knowledge is radically unlike ours. His knowledge may not be divided like ours into stories and narratives (chunks of information). The idea that God knows stories may well be just an accommodation to meet the inadequacies of our finite, limited understanding. Nevertheless it is hard to accept that what to us is appallingly ugly can be converted into beauty by its being subsumed into divine undifferentiated vision. Recall that God's vision of the possible must exactly parallel the actual act which could emerge. God's vision cannot be blurred - any subsuming must not allow the horrific visions He sees to be changed in any way. The Leibnizean wants God to see exactly what might happen. These visions are part of who God is. I think that such an understanding of God necessarily fills the divine beauty with ugliness.

\section{Conclusion}

It seems to me, then, that if we take the typical possible-worlds approach where God contemplates for all eternity every possibility, we have a problem. Some parts of God will be ugly. As far as I can see, there are four broad solutions to the problem.

(1) Admit that God is not beautiful, or say that God is only beautiful in part.

As I mentioned in a note to this essay, there is that strand of theological thinking that reckons that our (beautiful) God rose out of a more primeval Ground; He is the God that arose when the Ground rejected the ugliness in Himself. I fear that many philosophers and theologians would rather this happen than have one single question mark be put against what their view is of the comprehensiveness of the divine omniscience.

(2) Say that possible worlds are outside of God. He does not look within at the ugliness of possible worlds, but outwardly on an exterior necessarily existing ugliness. ${ }^{32}$

This compromises the divine aseity, but seems to preserve the divine beauty. Because it compromises God's aseity, I reject this solution to the problem. The price the solution demands is too high.

(3) Claim that there are no possible worlds in which God does not decide to defeat and transform evil into an unsentimental beauty. There are no darker, unredeemed possible worlds or possible stories. ${ }^{33}$ 
One problem with that is that it would result in making it a necessary truth that God redeems evil. We are all used to hearing the dictum that if something is true in every possible world, then, it is a necessary truth. So if it is true that God defeats evil in every possible world, then, it is a necessary truth that God redeems evil. This seems to limit the divine freedom and what we always suppose is the sheer, gratuitous nature of His grace. Another problem is that possible worlds are meant to be, in most possible-world semantics, the ground of our declarative statements; they are, Adams says, the 'fundamental objects of logic' ${ }^{34}$ When I talk of unredeemed worlds I seem to be talking of something. The possible world semanticist says that I am talking about possible unredeemed worlds. ${ }^{35}$

(4) Reject possible worlds completely and say with Arnauld that there are no merely possible things.

In correspondence with Leibniz, Arnauld rejects talk of possible worlds and possible things:

... I acknowledge in good faith that I have no idea of substances purely possible, that is to say, which God will never create. I am inclined to think that these are chimeras which we construct and that whatever we call possible substances, pure possibilities are nothing else than the omnipotence of God who, being a pure act, does not allow of these being a possibility in him. Possibilities, however, may be conceived of in the natures he has created, for, not being of the same essence throughout, they are necessarily composites of power and action. I can, therefore, think of them as possibilities. I can also do the same with an infinity of modifications which are within the power of these created natures, such as are the thoughts of intelligent beings, and the forms of extended substance. But I am very much mistaken if there is anyone who will venture to say that he has an idea of a possible substance as pure possibility ... . I am convinced that, although there is so much talk of these substances which are pure possibilities, they are, nevertheless, always conceived of only under the idea of those which God has actually created. We seem, therefore, able to say that outside of the things which God has created, or must create, there is no negative possibility but only an active and infinite power. ${ }^{36}$

I could say much in defence of Arnauld's claim, but now is not the time.${ }^{37}$ Let us leave the argument with these questions: have we got our emphasis right in modern philosophical theology with our primary preoccupation with notions of omniscience and omnipotence? Have we lost sight of the divine beauty amid the endless discussions about power and knowledge? It is my view that a rededication to the beauty of the divine being might well help us to re-think what it means for God to be maximally powerful and knowledgeable. ${ }^{38}$

\section{Notes}

1. In questioning possible worlds I join the growing band of those who reject the notion that God employs possible worlds in the processes of creation. See David Burrell Freedom and Faith in Three Traditions (Notre Dame IN: Notre Dame Press, 1993), 111-118; idem 'Creation and “actualism”: The dialectical 
dimension of philosophical theology', in David Burrell Faith and Freedom (Oxford: Blackwell Publishing, 2004), 76-90; James Ross Thought and World (Notre Dame IN: Notre Dame Press, 2008), 45-65. Barry Miller's thoughts tend in a similar direction. He rejects that common preconception that before their actuality individuals can be referred to; Barry Miller The Fullness of Being (Notre Dame IN: Notre Dame Press, 2002), 87-95. See also my Ontology and Providence in Creation: Taking Ex Nihilo Seriously (London: Continuum, 2008).

2. Wisdom of Solomon, 7.29-8.2 (New American Bible).

3. Augustine Confessions, Book X, vi, 8 (Oxford: Oxford University Press, 1991), 183 (translation slightly adapted). To keep with the traditional references to Wisdom as female I have slightly adapted some translations both here and below.

4. Ibid., Book X, xxvii, 38, 201.

5. Pseudo-Dionysius: The Complete Works (London: Classics of Western Spirituality, 1978), 76-77 (translation slightly adapted); quoted in Patrick Sherry Spirit and Beauty (London: SCM Press, 2002), 56.

6. Patrick Sherry and Richard Harries are just two of the scholars who have drawn attention to the neglect of the beauty of God in recent times. See Sherry Spirit and Beauty, 21-27; Richard Harries Art and the Beauty of God (London: Continuum, 1993), 1-17. See also Edward Oakes's essay 'The apologetics of beauty', where he looks at how the ugly is often glorified in modern art and culture. He tries to show (drawing upon the ideas of Von Balthasar as his chief inspiration) how the idea of beauty must be an integral part of the Christian witness; Edward Oakes 'The apologetics of beauty', in D. Treier, M. Husbands, \& R. Lundin (eds) The Beauty of God (Downers Grove IL: Intervarsity Press, 2008), 209-226.

7. Anselm Monologium, ch. 11 (La Salle IL: Open Court Publishing, 1962), 104 (translation slightly adapted).

8. Ibid., ch. 12, 105 (translation slightly adapted).

9. We need not enter the debate about whether possibility is best understood as maximally consistent sets of propositions, or whether it is best seen as sets of states of affairs, or, indeed, whether propositions just are states of affairs. If the reader is sceptical about possibility being understood to be propositional in content, he or she can adjust my parable so that God shows states of affairs to His audience. Whatever one chooses as one's preferred way of understanding possibility, some of those possibilities will be ugly - if, that is, we accept the possible-worlds account of the divine understanding.

10. It might be claimed that my complaint is not against possible worlds, but any comprehensive account of God's omniscience. I have argued elsewhere that rejecting possible worlds does not compromise divine omniscience. See Robson Ontology and Providence in Creation, 54-57. Possible worlds are especially iniquitous in my view since they are discrete, eternal, necessary, determinate, and are seen as part of the divine mind. I am not so sure that writers like Augustine (who undoubtedly believed in God's omniscience) would have been ready to accept possible worlds. Most writers (up to Leibniz) seemed content that God had ideas of humanity and equinity, rather than knowledge of individual essences like Socrates and Bucephalus.

11. The most standard formalization of modal logic $\left(\mathrm{S}_{5}\right)$ accepts that possibility is a matter of necessity; that is to say, whatever is possible is possible necessarily. So whatever is possible, will continue to be possible for all eternity. Even before the world existed and there was only God, then, murder, rape, torture, and all other moral horrors were possible. These possible horrors will continue, if we accept the possible-worlds' picture, to haunt reality forever.

12. Not all the ugly worlds that God would contemplate would be evil; some would just be horrible to look at, or just entirely without rhyme or reason. Consider the world whose only constituent is a snarling, ugly face inscribed on the surface of some rank sewage. Presumably (if there are possible worlds) this world (or its story) is present in the divine consciousness for all eternity.

13. For ease, I will refer to the possible-worlds' theorist as a 'Leibnizean' in honour of the chief inspiration of this way of understanding the divine mind.

14. There are some complex issues here. Some people fantasize about rape and murder. They do not want these things to become actual, however. They realize that actualization would be morally terrible: real people would get hurt. So they entertain certain evil possibilities without wanting them to become actual. However, most would accept that such fantasies are morally compromising. The line between fantasy and mere contemplation of an evil is quite hard to draw. For ease of presentation, I ignore this difficulty. 
15. The story would not even have to be told to anyone for it to be ugly. Even if Wisdom had kept her stories to herself, they would still have been in her mind - a kind of secret stain! Perhaps these secret stories would be even more worrying.

16. I deliberately use the word 'copy'. Part of my discomfort with possible-world accounts of the divine mind is what I see as its consequence that God inevitably has to yield to the eternal dictates of possible rapists and murderers. It is as if there are independent currents of sin swirling in the divine consciousness. (The number of these independent currents is infinitely multiplied by those who believe in middle knowledge.) This independence of the possible from the divine will is, of course, acknowledged by the Leibnizean. Leibniz himself explicitly rejected the idea proposed by Descartes that the logical laws themselves were subject to the divine will. Leibniz, in contrast, claimed that the logical laws depend upon the divine understanding, but not upon His will. I have no wish to endorse Descartes' universal possibilism. I think that the logical laws (say, for example, the law of non-contradiction) is somehow embedded in the divine being, but this acknowledgement of the existence of this law does not legitimize the inference that there are whole, determinate, possible worlds in the divine mind which already obey it.

17. Another way the Leibnizean might try to ameliorate the ugliness of God's stories is to say that God's knowledge of possibilities are not so much stories, but sets of truths or sets of propositions. So God knows the truth 'if Leatherface were to work in an abattoir, he would acquire an unhealthy interest in chainsaws'. God merely knowing sets of truths might seem less ugly. A proposition, it might be argued, is just a proposition - it is aesthetically neutral. I am not so sure - the set of possible truths about a possible galactic holocaust seems ugly and seems to constitute a story, a narrative, a way things might go. On God only knowing truths see William Lane Craig Time and Eternity: Exploring God's Relationship to Time (Wheaton IL: Crossway Books, 2001), 263-265.

18. David Brown in his commentary on Grünewald's Isenheim Altarpiece says that originally the painting was intended for a hospital 'which cared for those suffering from a particularly ravaging illness that produced gangrene, boils, blackened skin and muscular spasms'. Those suffering would be able to find some consolation in Christ sharing their pain. See David Brown Tradition and Imagination (Oxford: Oxford University Press, 1999), 351-352.

19. Of course, were all the ugliness eliminated by its being looked upon with hatred, there would no longer be much left to look upon!

20. It is also worth recalling that when Picasso painted Guernica he was reacting to an event outside of himself. He wanted to show the ugliness of what had happened. But God in His possible stories is not reacting to things outside of Himself; He is looking inwardly at the contents of His own mind. If, then, God hates the story of child rape and murder (which surely He does), is He hating a part of Himself? Do we have to agree with those theologians who have speculated about the existence of a divine darkness? If so, we must accept that God is not wholly beautiful. He contains ugliness as well as beauty.

21. Richard Harries argues for something like this in Art and the Beauty of God, 48-62.

22. There are some complex issues here. I suspect that a Leibnizean would try to remove any taint of moral imperfection on God's part by trying to show that evil can only be weakly actualized by God. He is, therefore, evil's weak grounding. Another way out is to claim that evil has no grounding at all. This was Leibniz's preferred option. See Gottfried Leibniz Theodicy (La Salle IL: Open Court Press, 1985), 140-141. Nevertheless, according to Leibniz, God still can see the story of evil's unfolding in His understanding. Leibniz says, 'where shall we find the source of evil? The answer is, that it must be sought in the ideal nature of the creature, in so far as this nature is contained in the eternal verities which are in the understanding of God, independently of his will ... . And [in the divine understanding] is found not only the primitive form of good, but also the origin of evil' (135-136).

There is no time to pursue these claims here, but I find the idea that evil's ontological status is somehow identical with a lack or privation to be deeply implausible. Certainly evil's existence can be explained by a lack or deficiency, but to identify it literally as a lack is to say something deeply puzzling. However, even if these replies were successful in rebutting the claim that God is the ultimate eternal ground of evil, it would not answer the central charge that having these stories as a part of God's being is compromising to the beauty of God. As we have just read, Leibniz says that part of God's understanding contains the 'origin of evil' - i.e. in the eternal deficiency of the possible creature in the mind of God. 
23. See, for example, G. Boyd 'The open theism view', in J. Beilby \& P. Eddy (eds) Divine Foreknowledge (Downers Grove IL: InterVarsity Press, 2001), 13-47.

24. I have tried to avoid this charge by having Wisdom in the parable tell some awe-inspiring, even terrifying stories. I do not think that God's beauty is safe or tamed. (As C. S. Lewis so rightly said, Aslan is not a tame lion!) I think that the terrifying can be beautiful. A story of child rape and murder, on the other hand, is terrifying and ugly - it is certainly not sublime! On the relationship between the sublime and the beautiful, see Jeremy Begbie 'Created beauty: J. S. Bach and the arts', in Treier, Husbands, \& Lundin The Beauty of God, 19-44.

25. Jeremy Begbie 'Beauty, sentimentality and the arts', in Treier, Husbands, \& Lundin The Beauty of God, 45-69.

26. Begbie talks about seeing the Easter events in two ways. In one view we see the events in the light of the Resurrection, as the crucified Lord eventually being vindicated. In another view we live through the trauma of the uncertainty of this transformation - as the disciples lived with the uncertainty of Easter Saturday. Begbie is very insistent (and I think rightly so) that God's eventual vindication of the crucified Lord is not a vindication of the moral horror of crucifixion. See Begbie, 'Beauty, sentimentality and the arts', 66. We cannot fit horror into a pattern which makes the horror itself beautiful. Another important point: any talk of God defeating evil must also look at the problem of hell where evil (and ugliness) seems eternalized. On this see Hans Urs von Balthasar Dare We Hope 'That All Men Will Be Saved'? (San Francisco CA: Ignatius Press, 1987).

27. There is a problem here. In what sense are possible worlds possible, if they could never be actualized? In what sense is something possible if it cannot (possibly) ever be or ever have been? And yet we hear some philosophers, following the inspiration of Alvin Plantinga The Nature of Necessity (Oxford: Oxford University Press, 1974), 169-174, saying that there are possible worlds that even God cannot actualize. William Lane Craig, for example, claims that God's free knowledge ranges over all possible worlds, but then, confronted with the counterfactuals of creaturely freedom, God finds that there are some worlds He cannot create, or which are not 'feasible' for Him; William Lane Craig The Only Wise God: The Compatibility of Divine Foreknowledge and Human Freedom (Eugene OR: Wipf \& Stock Publishers), 130-131, and idem 'The middle-knowledge view', in Beilby \& Eddy Divine Foreknowledge, 119-143, 122-123. I am always at a loss to understand how worlds are possible if it is absolutely impossible for the Ground of All Being to actualize them? It is almost as if these unactualizable creatures and worlds defy God before they even exist. Thus again, according to the Leibnizean, there are whole swathes of God utterly defiant to the divine wishes. This defiance remains stubbornly recalcitrant for all eternity.

28. Linda Zagzebski The Dilemma of Freedom and Foreknowledge (Oxford: Oxford University Press, 1991), 88.

29. Ibid. 89.

30. Ibid. 90-91.

31. Again, we need to note that orthodox Leibnizeans commit themselves to $\mathrm{S}_{5}$.

32. Richard Creel in Divine Impassibility (Cambridge: Cambridge University Press, 1986) puts forward the idea that alongside God there is a plenum representing every possibility.

33. I would agree, however, with Begbie that one cannot beautify horror by making it part of some grander narrative. So, even if the only worlds which are possible are those in which God defeats evil (and so the whole is good), there will still be areas of local ugliness. This local ugliness must be represented in the possible worlds that God scrutinizes prior to creation.

34. Robert Adams Leibniz: Determinist, Theist, Idealist (Oxford: Oxford University Press, 1994), 178.

35. The problem would be even worse for someone like Alvin Plantinga who accepts impossible worlds as part of his ontology; Plantinga The Nature of Necessity, 158. So even if we were to say that these worlds are somehow logically impossible, their ugliness as impossible worlds would continue to infect the divine being.

36. Gottfried Leibniz, Correspondence with Arnauld (La Salle IL: Open Court Publishing, 1902), 97.

37. See Robson Ontology and Providence in Creation, 101-105.

38. Acknowledgements: Fr Andrew Downie provided some very helpful comments on the paper and helped clarify some vital issues; David Burrell and John O'Callaghan read the paper and encouraged me to send it for publication; David Brown also read an earlier version of the paper, as did Medi Volpe. I am grateful to all of them for their time and help. 